\title{
Glass Sponges off the Newfoundland (Northwest Atlantic): Description of a New Species of Dictyaulus (Porifera: Hexactinellida: Euplectellidae)
}

\author{
Francisco Javier Murillo, ${ }^{1}$ Konstantin R. Tabachnick, ${ }^{2}$ and Larisa L. Menshenina ${ }^{3}$ \\ ${ }^{1}$ Instituto Español de Oceanografía, 36280 Vigo, Spain \\ ${ }^{2}$ Department of Benthic Fauna, P. P. Shirshov Institute of Oceanology, Russian Academy of Sciences, Nakhimovsky Prospekt 36, \\ Moscow 117997, Russia \\ ${ }^{3}$ Physical Department, Moscow State University, Moscow 119991, Russia
}

Correspondence should be addressed to Konstantin R. Tabachnick; tabachnick@mail.ru

Received 7 April 2013; Accepted 10 June 2013

Academic Editor: Jakov Dulčić

Copyright (C) 2013 Francisco Javier Murillo et al. This is an open access article distributed under the Creative Commons Attribution License, which permits unrestricted use, distribution, and reproduction in any medium, provided the original work is properly cited.

Three species of hexactinellid sponges: Aphrocallistes beatrix beatrix Gray, Asconema foliata (Fristedt), and Dictyaulus romani sp. n. were collected off the Flemish Cap in the Flemish Pass and from the Grand Banks off the Newfoundland (northwest Atlantic) during different surveys on board of Spanish RV Vizconde de Eza and RV Miguel Oliver.

\section{Introduction}

The hexactinellid fauna of the northwest Atlantic is remaining poorly investigated up to now. A unique notable population of Vazella pourtalesi Schmidt was recently described from the adjacent area (the shelf of Scotia) [1], a monospecific genus previously known by few specimens from two findings in the Caribbean Sea off Florida and off Azores [2].

The present work complements data on hexactinellid fauna of the northwest Atlantic (the Newfoundland area). It is based on materials collected on groundfish bottom trawl surveys and on NEREIDA cruises. We describe a new species of Dictyaulus, a genus known for a long time by a single representative from the Indian Ocean, and recently two species from the central Pacific [3] and the north Atlantic [4] were described.

\section{Material and Methods}

Material was collected by groundfish bottom trawl surveys by the RV Vizconde de Eza supported by the Instituto Español de Oceanografía and the European Union (methodology used is described in [5]) and from rock dredge samples on board the RV Miguel Oliver sustained by Spain's General Secretariat of the Sea (Secretaría General del Mar) in the framework of the NEREIDA (a multidisciplinary research project). Samples were fixed in $70^{\circ}$ ethanol.

Spicules were dissociated using solution of $\mathrm{K}_{2} \mathrm{Cr}_{2} \mathrm{O}_{7}$, fresh water, and $\mathrm{H}_{2} \mathrm{SO}_{4}$ then washed in fresh, water, and dried. Spicules were mounted in Canada balsam and analysed (including measurements) using light microscopy.

Type materials are stored in the National Museum of Natural Sciences in Madrid (Spain); other specimens are deposited in the Instituto Español de Oceanografía, Vigo (Spain); small fragments and slides for the light microscopy of all investigated specimens are treasured in the P.P. Shirshov Institute of Oceanology, Russian Academy of Sciences, Moscow (Russia).

Taxonomy

Hexactinellida Schmidt, 1870

Hexasterophora Schulze, 1886

Hexactinosida Schrammen, 1903

Aphrocallistidae Gray, 1867

Aphrocallistes aff. beatrix beatrix Gray, 1858 


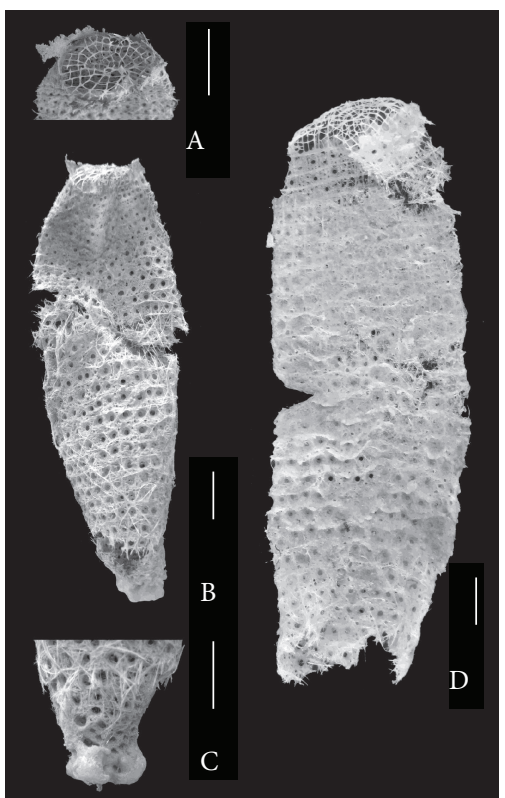

FIgURE 1: Dictyaulus romani sp. n. A: sieve plate of holotype. B: holotype, external shape. C: bottom basidictyonal plate of holotype. D: paratype, external shape. Scale bar $20 \mathrm{~mm}$.

Material Examined. IEO: RV Vizconde de Eza, St. FC07 L19, 25.06.2007, $46^{\circ} 43,62^{\prime}-42,02^{\prime} \mathrm{N} 46^{\circ} 19,40^{\prime}-18,58^{\prime}$ W, depth $404 \mathrm{~m}$.

Description. Three small fragments of $20 \times 15 \mathrm{~mm}, 15 \times$ $10 \mathrm{~mm}$, and $15 \times 5 \mathrm{~mm}$ were studied.

Remarks. This specimen does not contain any loose spicules; hence its precise identification is impossible, while their morphology is typical for the genus. Nevertheless due to the location of this specimen and data on distribution of representatives of this genus [6], and the name Aphrocallistes beatrix beatrix is assigned with minimal hesitations Figures 1 , 2, and Table 1 .

\section{Lyssacinosida \\ Euplectellidae Gray, 1867 \\ Corbitellinae Gray, 1872 \\ Dictyaulus Schulze, 1895 \\ Dictyaulus romani sp. $\mathrm{n}$.}

Etymology. The species is named in the honor of Mrs. Esther Roman, whose activity in the Newfoundland investigations allowed the capturing of these specimens.

Material Examined. Holotype MNCN 1.04/8 RV Vizconde de Eza, St. FN3L06 L99, 18.08.2006, 46 $08,25^{\prime}-06,72^{\prime} \mathrm{N}$ $46^{\circ} 50,74^{\prime}-50,46^{\prime}$ W, depth 1394-1418 m. Paratype MNCN 1.04/9 RV Vizconde de Eza, St. FC07 L170, 18.07.2007, $46^{\circ} 09,21^{\prime}-09,15^{\prime} \mathrm{N} 45^{\circ} 46,11^{\prime}-48,33^{\prime}$ W, depth $1332-1488 \mathrm{~m}$.

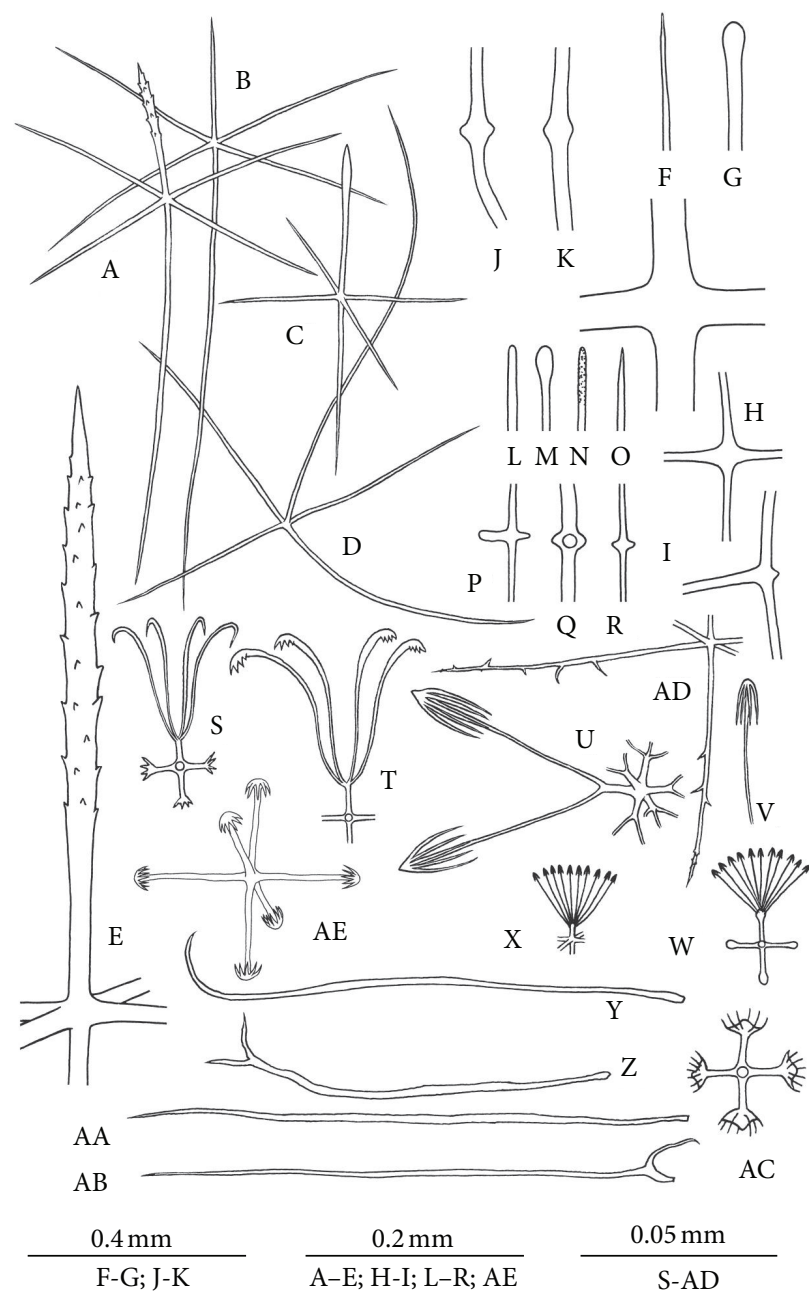

Figure 2: Spicules of Dictyaulus romani sp. n. A-AD: paratype. AE: holotype. A-C: dermal hexactins. D: atrial pentactin. E: hypodermal hexactin or prostalia oscularia. F-G: large choanosomal stauractin and its outer ends. H: small choanosomal stauractin. I: choanosomal tauactin. J-K: large choanosomal diactins. L-R: small choanosomal diactins. S: drepanocome. T: floricome. U-V: anchorate macrodiscohexaster and its secondary ray. W-X: spherical microdiscohexasters. $\mathrm{Y}-\mathrm{AC}$ : fragments of oxyhexaster: secondary rays $(\mathrm{Y}-\mathrm{AB})$ and primary rosette $(\mathrm{AC})$. AD: spiny oxyhexactin. AE: discohexactin.

\section{Description}

Body Morphology. The holotype is tubular $200 \mathrm{~mm}$ high, $47 \mathrm{~mm}$ in diameter, $18 \mathrm{~mm}$ in diameter at base (basiphytous), and $32 \mathrm{~mm}$ in diameter of upper part carrying the sieve plate. The paratype is $265 \mathrm{~mm}$ high, $50 \mathrm{~mm}$ in diameter, and at base it is broken. Numerous round or oval lateral oscula $0.5-3 \mathrm{~mm}$ in diameter penetrate thin $0.5-0.8 \mathrm{~mm}$ walls of the specimen. The sieve plate is colander in structure, and it is made of the beams with meshes usually square, sometimes rectangular, or triangular with sides $2-5 \mathrm{~mm}$ long. A fine, circular, about $5 \mathrm{~mm}$ high structure of small, loose spicules is situated above and around the main osculum of both specimens. No prostasia lateralia was observed in this specimen. 
TABLE 1: Spicule dimensions (in mm) Dictyaulus romani sp. $\mathrm{n}$.

\begin{tabular}{|c|c|c|c|c|c|c|c|c|c|c|}
\hline & \multicolumn{5}{|c|}{ Holotype } & \multicolumn{5}{|c|}{ Paratype } \\
\hline & $n$ & $\min$. & $\max$. & avg & std & $n$ & $\min$. & $\max$. & avg & std \\
\hline$L$ dermal hexactin distal ray & 24 & 0.037 & 0.252 & 0.151 & 0.044 & 35 & 0.104 & 0.211 & 0.148 & 0.024 \\
\hline$L$ dermal hexactin tangential ray & 25 & 0.104 & 0.185 & 0.143 & 0.018 & 28 & 0.111 & 0.241 & 0.159 & 0.035 \\
\hline$L$ dermal hexactin proximal ray & 18 & 0.141 & 0.481 & 0.310 & 0.104 & 18 & 0.093 & 0.525 & 0.284 & 0.147 \\
\hline$L$ atrial pentactin tangential ray & 6 & 0.278 & 0.414 & 0.335 & 0.050 & 7 & 0.200 & 0.500 & 0.370 & 0.119 \\
\hline$L$ atrial pentactin ray directed inside body & 4 & 0.352 & 0.444 & 0.389 & 0.040 & 4 & 0.252 & 0.444 & 0.352 & 0.107 \\
\hline$D$ drepanocome & 12 & 0.059 & 0.081 & 0.074 & 0.006 & 25 & 0.072 & 0.101 & 0.092 & 0.007 \\
\hline$d$ drepanocome & 12 & 0.015 & 0.019 & 0.017 & 0.002 & 25 & 0.014 & 0.020 & 0.017 & 0.002 \\
\hline$D$ floricome & 25 & 0.089 & 0.118 & 0.105 & 0.007 & 26 & 0.072 & 0.140 & 0.097 & 0.012 \\
\hline$d$ floricome & 25 & 0.015 & 0.030 & 0.020 & 0.004 & 26 & 0.014 & 0.018 & 0.017 & 0.001 \\
\hline$D$ spiny hexactin & 25 & 0.178 & 0.266 & 0.220 & 0.025 & 27 & 0.133 & 0.227 & 0.175 & 0.024 \\
\hline$D$ pappocome & 25 & 0.259 & 0.333 & 0.300 & 0.016 & 25 & 0.169 & 0.263 & 0.216 & 0.022 \\
\hline$d$ pappocome & 1 & 0.016 & 0.016 & 0.016 & & 25 & 0.014 & 0.026 & 0.019 & 0.003 \\
\hline$D$ large discohexaster & 2 & 0.118 & 0.141 & 0.130 & 0.016 & 4 & 0.072 & 0.108 & 0.097 & 0.017 \\
\hline$d$ large discohexaster & 2 & 0.022 & 0.036 & 0.029 & 0.009 & 4 & 0.014 & 0.016 & 0.015 & 0.001 \\
\hline$D$ small discohexaster & 11 & 0.032 & 0.065 & 0.048 & 0.010 & 20 & 0.022 & 0.054 & 0.040 & 0.007 \\
\hline$d$ small discohexaster & 11 & 0.014 & 0.020 & 0.017 & 0.002 & 20 & 0.007 & 0.017 & 0.012 & 0.003 \\
\hline$D$ discohexactin & 3 & 0.185 & 0.215 & 0.195 & 0.017 & & & & & \\
\hline
\end{tabular}

$L$ : length; $D$ : diameter; $d$ : diameter of primary rosette.

Spicules. Choanosomal spicules are principalia (stauractins, some tauactins, and diactins), rare pinular hexactins, and additional spicules (comitalia: smaller stauractins, tauactins, diactins, and, maybe, pentactins). Principalia are large stauractins with rays $10 / 0.06-0.11 \mathrm{~mm}$, and their outer ends are smooth, conically pointed, or rounded. The choanosomal spicules of smaller sizes have rays $0.48-2.8 / 0.004-0.015 \mathrm{~mm}$, and their outer ends are conically pointed, or rounded, smooth or rough. The spicules of the sieve plate are similar to the choanosomal ones, both large and small, but most spicules of the sieve plate are curved diactins. The large diactins of the sieve plate have a widening in the middle, and they are about $3 / 0.02-0.08 \mathrm{~mm}$. The small diactins of the sieve plate $0.9-3 / 0.004-0.009 \mathrm{~mm}$ have a widening in the middle or 2 or 4 tubercles. Some hexactins, found among the spicules of the sieve plate, have rays $0.08-0.3 / 0.020-$ $0.025 \mathrm{~mm}$. The large pinular hexactins have distal ray pinular $0.6-1.2 / 0.06 \mathrm{~mm}$, and the diameter of the tangential rays is smaller-about $0.04 \mathrm{~mm}$; only one broken spicule of this type was observed. Maybe this spicule is principalia of the sieve plate which forms the principal attachment of the sieve plate to the margin of the main osculum. Fusion between choanosomal spicules was observed in the holotype only in some large spicules at the basal part.

Dermalia are hexactins smaller than that described above; they have distal rays lanceolate, lanceolate-pinular, or stout, similar to other rays of these spicules. The distal ray of dermal hexactin is $0.037-0.252 \mathrm{~mm}$ long up to $0.03 \mathrm{~mm}$ in diameter at the thickest part; tangential rays are 0.104$0.241 \mathrm{~mm}$ long, their proximal ray is $0.093-0.525 \mathrm{~mm}$ long, the diameter of these rays is $0.004-0.007 \mathrm{~mm}$, and their outer ends are conically pointed, smooth. Atrialia are pentactins with tangential rays $0.200-0.500 \mathrm{~mm}$ long, their ray directed inside the body is $0.252-0.444 \mathrm{~mm}$ long, the diameter of these rays is $0.004-0.007 \mathrm{~mm}$, and the outer ends are equal to those of dermal hexactins and to small choanosomal spicules. These pentactins are very rarely found, and it is possible that these pentactins are choanosomal spicules (common in many representatives of the subfamily).

Microscleres. Spicules of this type are numerous: drepanocomes, floricomes, pappocomes, large and small discohexasters, and spiny hexactins; discohexactins were unique (found in the holotype only). The drepanocomes with 47 secondary rays are $0.059-0.101 \mathrm{~mm}$ in diameter, and their primary rosette is $0.014-0.020 \mathrm{~mm}$ in diameter. The floricomes have 4-7 secondary rays, each secondary ray has 25 teeth, the diameter of the floricomes is $0.072-0.140 \mathrm{~mm}$, and their primary rosette is $0.014-0.030 \mathrm{~mm}$ in diameter. The spiny hexactins are $0.133-0.266 \mathrm{~mm}$ in diameter. The pappocomes, spicules with secondary rays approximately 1115 in number, are distributed in slightly widened tufts (as it may be suggested since these spicules were found always broken: secondary rays separated from the primary rosettes); the secondary rays are straight and oxyoidal, rarely onychoidal, curved oxyoidal and rarely spiny. The pappocomes are $0.169-$ $0.333 \mathrm{~mm}$ in diameter, and their primary rosette is $0.014-$ $0.026 \mathrm{~mm}$ in diameter. The large discohexasters with 2-3 secondary rays are rare, they are $0.072-0.141 \mathrm{~mm}$ in diameter, and their primary rosette is $0.014-0.036 \mathrm{~mm}$ in diameter. The large discohexasters have anchorate discs with umbel $0.015-0.034 \mathrm{~mm}$ long and $0.007-0.016 \mathrm{~mm}$ in diameter. The small discohexasters with numerous secondary rays are $0.022-0.065 \mathrm{~mm}$ in diameter, and their primary rosette is $0.007-0.020 \mathrm{~mm}$ in diameter. Their discs are also anchorate with umbel $0.004-0.007 \mathrm{~mm}$ long and $0.002-0.003 \mathrm{~mm}$ in 
diameter. The large discohexactins were found in the lower part of the holotype specimen, and they are $0.185-0.215 \mathrm{~mm}$ in diameter.

Remarks. Until now the genus Dictyaulus comprised 3 species: D. elegans Schulze, 1895 [7] (NW Indian Ocean); D. starmeri Tabachnick and Levi, 2004 [3] (SE Pacific); and D. marecoi Tabachnick and Collins, 2008 [4] (N Mid-Atlantic). Huge discoidal spicules in Dictyaulus are discohexasters in D. elegans, discasters in D. starmeri, and discohexactins in $D$. romani; in $D$. marecoi such spicules were not found as well as in the paratype of $D$. romani, described above. Specific feature of the new species is presence of pappocomes and their derivatives with onychoidal outer ends and secondary rays carrying some spines. As for other spicules the species from the Atlantic Ocean are very similar.

Rossellidae Schulze, 1885

Rossellinae Schulze, 1885

Asconema Kent, 1870

Asconema foliata (Fristedt, 1887)

Material Examined. IEO: RV Vizconde de Eza, St. PLA07 L55(1); L55(2); L55(3); L55(4), 10.06.2007, 42 51,59' -52,73' N $49^{\circ} 53,61^{\prime}-52,10^{\prime} \mathrm{W}$, depth 337-334 m. St. PLA07 L61(1); L61(2); L61(3), 11.06.2007, $43^{\circ} 05,86^{\prime}-07,29^{\prime} \mathrm{N} 49^{\circ} 29,92^{\prime}$ $29,60^{\prime} \mathrm{W}$, depth 629-656 m. St. PLA07 L70(1); L70(2), 12.06.2007, $43^{\circ} 20,26^{\prime}-21,57^{\prime} \mathrm{N} 49^{\circ} 14,37^{\prime}-13,52^{\prime} \mathrm{W}$, depth 640-656 m. St. PLA07 L72(1); L72(2), L72(3), 13.06.2007, $43^{\circ} 30,37^{\prime}-30,40^{\prime} \mathrm{N} 49^{\circ} 12,74^{\prime}-14,88^{\prime} \mathrm{W}$, depth 390-418 m. St. PLA07 L93, 17.06.2007, $45^{\circ} 24,90^{\prime}-23,83^{\prime} \mathrm{N} 48^{\circ} 21,28^{\prime}$ $22,77^{\prime}$ W, depth 1249-1266 m. St. PLA07 L94, 17.06.2007, $45^{\circ} 24,97^{\prime}-26,11^{\prime} \mathrm{N} 48^{\circ} 26,37^{\prime}-25,10^{\prime} \mathrm{W}$, depth 1003-1000 m. St. FC07 L18, 25.06.2007, $46^{\circ} 51,49^{\prime}-50,23^{\prime}$ N $46^{\circ} 27,82^{\prime}$ $26,35^{\prime}$ W, depth 423-420 m. St. FC07 L20, 25.06.2007, $46^{\circ} 37,14^{\prime}-35,87^{\prime}$ N $46^{\circ} 15,74^{\prime}-14,01^{\prime} \mathrm{W}$, depth $407 \mathrm{~m}$. St. FC07 L22(1); L22(2), 26.06.2007, $46^{\circ} 30,39^{\prime}-29,33^{\prime} \mathrm{N} 46^{\circ} 15,42^{\prime}$ $13,42^{\prime}$ W, depth 494-498 m. St. FC07 L26, 26.06.2007, $46^{\circ} 26,92^{\prime}-28,47^{\prime} \mathrm{N} 45^{\circ} 45,24^{\prime}-46,34^{\prime} \mathrm{W}$, depth 538-492 m. St. FC07 L44, 29.06.2007, $46^{\circ} 44,81^{\prime}-46,23^{\prime} \mathrm{N} 44^{\circ} 07,03^{\prime}-05,52^{\prime}$ W, depth 480-471 m. St. FC07 L45, 29.06.2007, $46^{\circ} 55,01^{\prime}$ $56,44^{\prime} \mathrm{N} 43^{\circ} 54,86^{\prime}-53,50^{\prime} \mathrm{W}$, depth 528-539 m. St. FC07 L48, 30.06.2007, $47^{\circ} 00,05^{\prime}-01,76^{\prime} \mathrm{N} 44^{\circ} 34,24^{\prime}-34,57^{\prime} \mathrm{W}$, depth 138-148 m. St. FC07 L58, 01.07.2007, $47^{\circ} 14,28^{\prime}-15,96^{\prime}$ $\mathrm{N} 43^{\circ} 45,39^{\prime}-45,91^{\prime}$ W, depth 647-642 m. St. FC07 L59, 01.07.2007, $47^{\circ} 28,83^{\prime}-30,51^{\prime} \mathrm{N} 43^{\circ} 50,15^{\prime}-50,46^{\prime} \mathrm{W}$, depth 638645 m. St. FC07 L74, 03.07.2007, $48^{\circ} 13,60^{\prime}-14,76^{\prime} \mathrm{N} 44^{\circ} 43,85^{\prime}$ $45,77^{\prime}$ W, depth 596-599 m. St. FC07 L75, 03.07.2007, $48^{\circ} 14,89^{\prime}-15,66^{\prime} \mathrm{N} 44^{\circ} 52,92^{\prime}-55,22^{\prime} \mathrm{W}$, depth 567-570 m. St. FC07 L123, 09.07.2007, $48^{\circ} 17,51^{\prime}-16,03^{\prime} \mathrm{N} 45^{\circ} 45,05^{\prime}-46,14^{\prime}$ W, depth 957-947 m. St. FN3L09 L5(1); L5(2), 26.07.2009, $48^{\circ} 03,90^{\prime}-04,21^{\prime} \mathrm{N} 47^{\circ} 17,77^{\prime}-19,93^{\prime} \mathrm{W}$, depth 634-639 m. St. FN3L10 L44(1); L44(2); L44(3), 03.08.2010, $47^{\circ} 29,47^{\prime}-28,02^{\prime}$ $\mathrm{N} 46^{\circ} 44,74^{\prime}-45,35^{\prime} \mathrm{W}$, depth $1175 \mathrm{~m}$. St. FN3L10 L64(1); L64(2); L64(3), 07.08.2010, $46^{\circ} 45,72^{\prime}-44,23^{\prime} \mathrm{N} 47^{\circ} 05,53^{\prime}-$ $05,22^{\prime} \mathrm{W}$, depth 1024-1085 m. RV Miguel Oliver, St. NEREIDA 0710 RD88-41 19.07.2010, $45^{\circ} 22,35^{\prime}-22,06^{\prime} \mathrm{N} 48^{\circ} 34,05^{\prime}-33,57^{\prime}$
W, depth 676-700 m. St. NEREIDA 0710 DR93-60 24.07.2010, $44^{\circ} 32,46^{\prime}-31,92^{\prime} \mathrm{N} 48^{\circ} 56,45^{\prime}-56,25^{\prime} \mathrm{W}$, depth 1167-1382 m.

\section{Description}

Body Morphology. These sponges are presented by broken fragments of thin walls $0.5-2 \mathrm{~mm}$ thick.

Spicules. Choanosomal spicules are diactins. Hypodermalia are smooth pentactins. Hypoatrialia are also pentactins with equal hypodermal ones; they were found only in some specimens in low amounts. Dermalia are pentactins with pinular rays distally directed, a short rudiment instead of the sixth ray has proximal direction, and the outer ray tips are rounded. Atrialia are large hexactins with pinular rays directed into the atrial cavity and pentactins smaller than dermal ones, with thinner rays and conically pointed outer ends, and their pinular rays are directed into the atrial cavity.

Microscleres. Oxyoidal microscleres are common, and they are oxyhexactins, oxyhexasters, and oxyhemihexasters. Discoidal microscleres are represented by spherical microdiscohexasters (found in all specimens) and low amounts of macrodiscasters (found in two specimens). In FC07 L48 a single macrodiscaster $0.089 \mathrm{~mm}$ in diameter with primary rosette $0.015 \mathrm{~mm}$ in diameter was found. In FC07 L26 we observed two macrodiscohexasters with very short primary rays, and they are $0.118-0.126 \mathrm{~mm}$ in diameter with primary rosettes $0.019-0.022 \mathrm{~mm}$ in diameter.

Remarks. A unique feature of the specimens collected off the Newfoundland is rarity of large discoidal microscleres (which were considered to be important in the species identification by [8]). Meanwhile, this is the largest series of representatives of this species, and this unique feature may be an important specific character as well.

\section{Abbreviations}

$\begin{array}{ll}\text { Avg: } & \text { Average } \\ \text { NEREIDA: } & \text { The project "NAFO" "potEntial vulnerable } \\ & \text { marine Ecosystems"-Impacts of Deep-seA } \\ & \text { fisheries } \\ & \text { Instituto Español de Oceanografía, Vigo } \\ \text { IEO: } & \text { (Spain) } \\ \text { MNCN: } & \text { National Museum of Natural Sciences in } \\ & \text { Madrid (Spain) } \\ n: & \text { Number of measurements } \\ \text { Std: } & \text { Standard deviation. }\end{array}$

\section{Acknowledgments}

The authors would like to acknowledge the scientific staff involved in NEREIDA surveys and NAFO groundfish bottom trawl surveys and the heads of these surveys, especially Mrs. Esther Roman, for facilitating the data collection, and the research vessels crews (RV Vizconde de Eza and RV Miguel Oliver) for assistance at the sea. They appreciate Dr. D. Janussen for her critical notes and the partial financial support of RFBR (research Grant 13-04-01332a). 


\section{References}

[1] S. D. Fuller, Diversity of marine sponges in the Northwest Atlantic [Ph.D. thesis], Dalhousie University, Halifax, Canada, 2011.

[2] K. R. Tabachnick, "Rossellidae Schulze, 1885," in Systema Porifera: A Guide to the Classification of Sponges, J. N. A. Hooper and R. W. M. Van Soest, Eds., pp. 1441-1504, Kluwer Academic/Plenum Publishers, New York, NY, USA, 2002.

[3] K. R. Tabachnick and C. Lévi, "Lyssacinosida du Pacifique sudouest (Porifera: Hexactinellida). Bruce A Marshall \& Bertran Richer de Forges," in Tropical Deep-Sea Benthos, vol. 23, pp. 1170, 2004, Mémoires du Museum national d'Histoire naturelle.

[4] K. R. Tabachnick and A. G. Collins, "Glass sponges (Porifera, Hexactinellida) of the northern Mid-Atlantic Ridge," Marine Biology Research, vol. 4, no. 1-2, pp. 25-47, 2008.

[5] F. J. Murillo, P. D. Muñoz, J. Cristobo et al., "Deep-sea sponge grounds of the Flemish Cap, Flemish Pass and the Grand Banks of Newfoundland (Northwest Atlantic Ocean): distribution and species composition," Marine Biology Research, vol. 8, no. 9, pp. 842-854, 2012.

[6] H. M. Reiswig, "Family Aphrocallistidae Gray, 1867," in Systema Porifera: A Guide to the Classification of Sponges, J. N. A. Hooper and R. W. M. Van Soest, Eds., pp. 1182-1286, Kluwer Academic/Plenum Publishers, New York, NY, USA, 2002.

[7] F. E. Schulze, Hexactinelliden des indischen Oceanes. II. Die Hexasterophora, Abhandlungen der Preussischen Akademie der Wissenschaften, Berlin, Germany, 1895.

[8] K. R. Tabachnick and L. L. Menshenina, "Revision of the genus Asconema (Porifera: Hexactinellida: Rossellidae)," Journal of the Marine Biological Association of the United Kingdom, vol. 87, no. 6, pp. 1403-1429, 2007. 

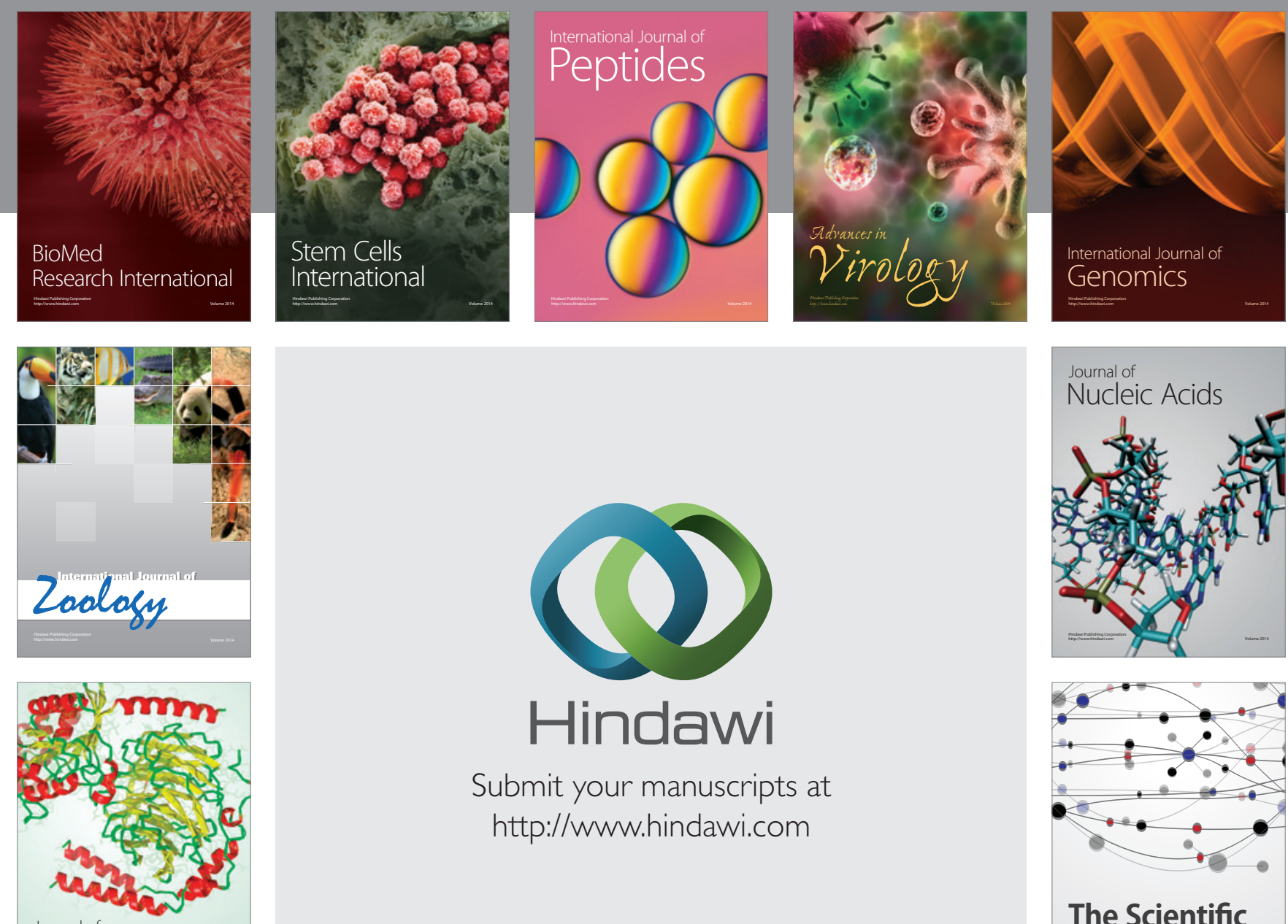

Submit your manuscripts at

http://www.hindawi.com

Journal of
Signal Transduction
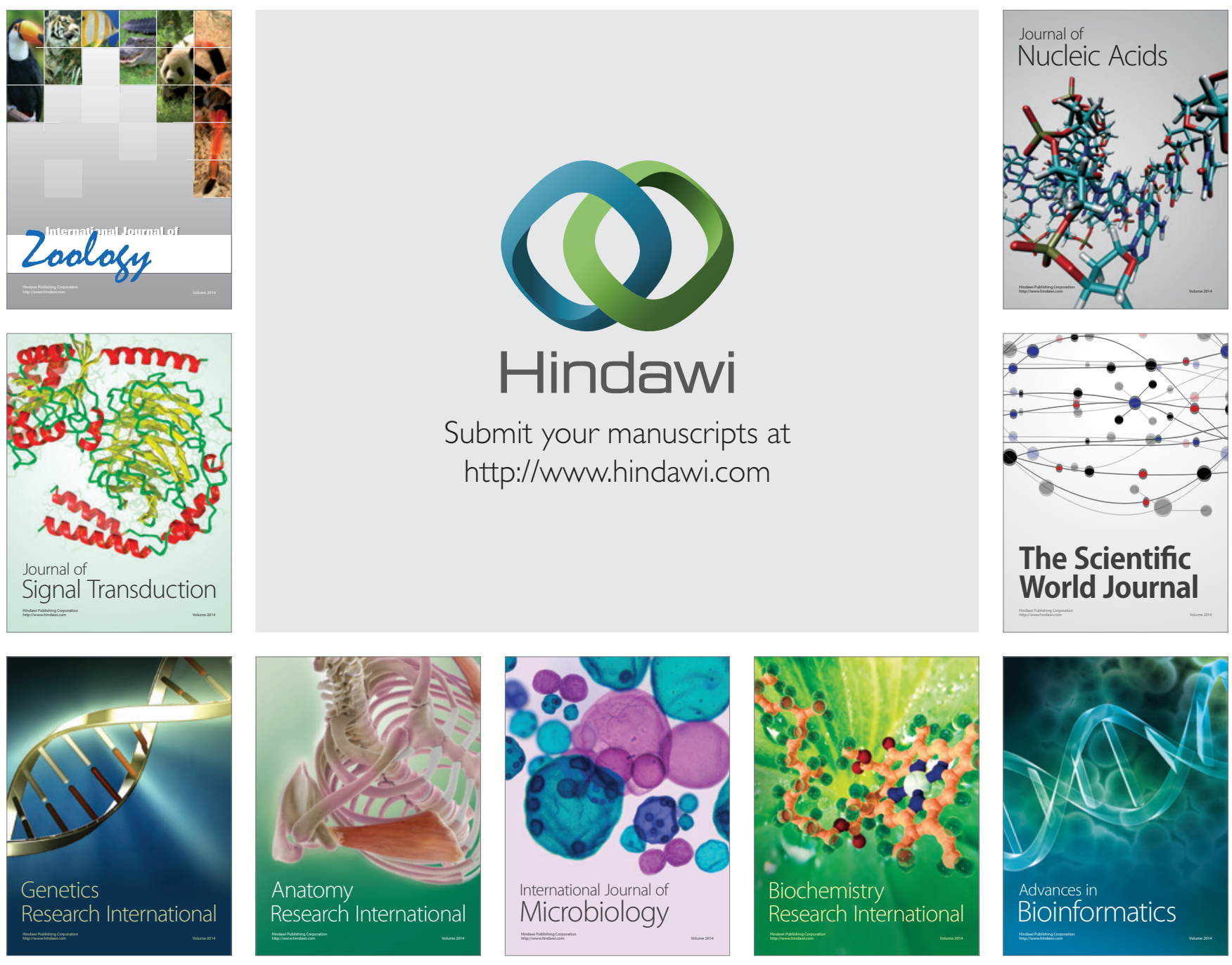

The Scientific World Journal
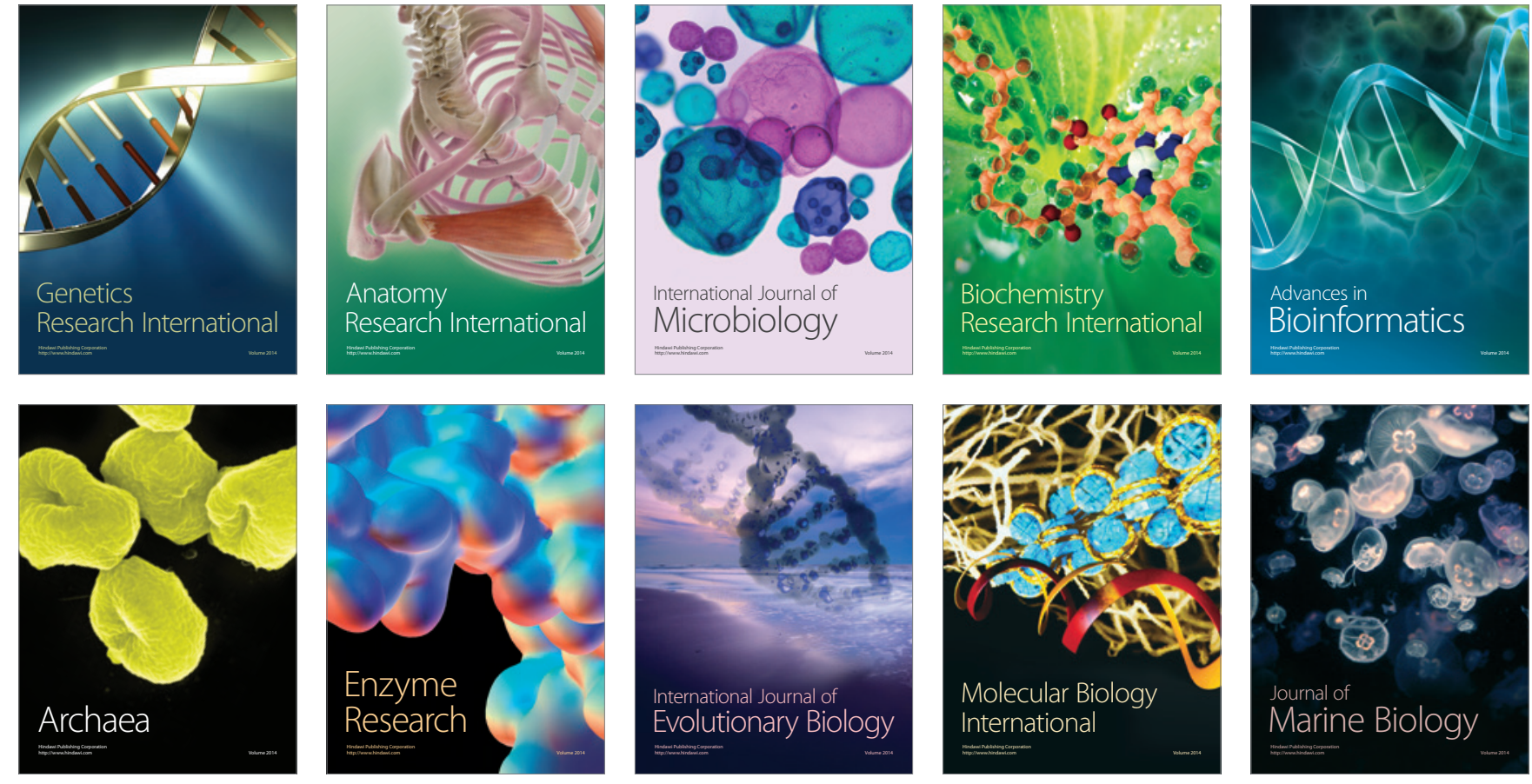